\title{
Host Gene Polymorphisms in Relation to Helicobacter Pylori Infection and Associated Diseases in a Population Based Cohort
}

\author{
Anna Ryberg ${ }^{\mathrm{a}, \mathrm{b}}$, Fredrik Petersson ${ }^{\mathrm{c}}$, Stefan Redeen ${ }^{\mathrm{b}}$, Olle Eriksson ${ }^{\mathrm{d}}$, Kurt Borch ${ }^{\mathrm{b}, \mathrm{e}}$
}

\begin{abstract}
Background: This prospective population based cohort study explores possible associations between host gene polymorphisms, blood group and life style factors on the one hand, and Helicobacter pylori infection, peptic ulcer, and the grade of inflammation, atrophy and intestinal metaplasia of the gastric mucosa, on the other hand.
\end{abstract}

Methods: The study population (472 volunteers) has previously undergone screening with gastroduodenoscopy, biopsy and blood sampling. The host gene polymorphisms of IL1B-31C/T, IFNGR1$56 \mathrm{~T} / \mathrm{C}$, the IL1RN VNTR in exon 2 and the HLA-DRB1 gene alleles were analyzed using PCR and pyrosequencing.

Results: $H$. pylori infection was negatively related to HLA DRB $1 * 03$ (odds ratio (OR) 95\% CI: 0.388 - 0.989) and was more frequent in individuals with blood group $\mathrm{O}$ than $\mathrm{A}$ (OR 95\% CI: 1.121 - 2.677). There was a lower risk of moderate to severe inflammation in the antrum among individuals with IL1B-31 TC compared to CC carriers (OR 95\% CI: 0.094 - 0.733). The IL1RN*L2 genotype was associated with higher risk of IM in the antrum than the *LL genotype (OR 95\% CI: 1.570 - 15.878). There was a negative relation between the HLA DRB1 alleles *04 (OR 95\% CI: $0.234-0.831$ ) and $* 08$ (OR 95\% CI: $0.013-0.915$ ), and IM in the

Manuscript accepted for publication December 6, 2013

\footnotetext{
${ }^{a}$ Department of Clinical Microbiology, Centre for Diagnostics, County Council of Ostergotland, Sweden

${ }^{b}$ Department of Clinical and Experimental Medicine, Faculty of Health Sciences, Linkoping University, Sweden

${ }^{c}$ Department of Pathology, National University Health System Singapore. Previously Department of Pathology, Karolinska University Hospital, Stockholm, Sweden

${ }^{\mathrm{d}}$ Department of Computer and Information Science, Faculty of Arts and Sciences, Linkoping University, Sweden

${ }^{\mathrm{e}}$ Corresponding author: Kurt Borch, Department of Clinical and

Experimental Medicine, Faculty of Health Sciences, Linkoping

University, S-58185 Linkoping, Sweden. Email: kurt.borch@liu.se
}

doi: http://dx.doi.org/10.4021/gr578w antrum.

Conclusion: The IL1RN VNTR and the IL1 $1-31$ alleles seem to be associated with intestinal metaplasia of the corpus mucosa and the grade of inflammation of the antrum, respectively. However, no unambiguous correlations could be identified between the host polymorphisms and the occurrence of $H$. pylori infection, peptic ulcer, and the grade of inflammation, atrophy and IM of the gastric mucosa.

Keywords: Atrophy; Gastritis; Peptic ulcer; Pyrosequencing; Stomach

\section{Introduction}

Helicobacter pylori (H. pylori) infection is associated with gastroduodenal diseases, such as peptic ulcer (PU), the premalignant condition atrophic gastritis (AG), gastric carcinoma (GC) and gastric mucosa associated lymphoid tissue (MALT) lymphoma [1]. Infection with these Gram-negative, microaerophilic bacteria is often life long, but exactly how H. pylori eludes the immune defence system is still not clear. Previous studies indicate that a combination of host gene polymorphisms, $H$. pylori virulence genes and environmental factors determines the outcome of the infection $[2,3]$.

Several host gene variations have been related to $H$. pylori infection and the development of associated gastroduodenal diseases. Interleukin-1 $\beta$ (IL1 $\beta$ ) and interleukin-1 receptor antagonist (IL1RN) gene polymorphisms have been found to be associated with increased risk of $\mathrm{AG}, \mathrm{GC}$ and duodenal ulcer (DU) $[4,5]$, but contradictory results have been reported $[6,7]$.

A recent meta-analysis [7] concluded that the IL1 receptor antagonist gene contains a variable number of tandem repeats (VNTR), where a short variant, containing two 86bp-repeats, is associated with GC, specifically in nonAsian populations. However, the authors could not find an overall correlation between cancer and polymorphisms in the promoter region of the very potent gastric acid secretion inhibitor IL1 $\beta$, except the finding of a reduced risk of cancer 
in IL1 1 -31C carriers in Asian populations. An earlier metaanalysis [8] concluded that there is an increased risk of GC associated with IL1B-511T and IL1RN*2 alleles in Caucasians, but not in Asians, and that there is a trend towards an association between IL1B-31C and GC in Caucasians.

IFNGR1 is the ligand-binding subunit of the interferon gamma receptor dimer. By genome wide linkage analysis, Thye et al (2003) [9] found increased anti-H. pylori serum immunoglobulin G levels among Senegalese siblings, who were homozygous or heterozygous carriers of the IFNGR1$56 \mathrm{~T}$ variant. Since then, several studies have indicated that there is a more general association between -56C/T SNP and human pathology related to both bacteria and viruses, the IFNGR1-56CC genotype being associated with protection from TB [10] and -56C with spontaneous clearance of hepatitis B virus [11]. Zhou et al [11] also showed that the IFNGR-56C variant is associated with higher transcription level than $-56 \mathrm{~T}$.

The human leukocyte antigen gene DRB1 encodes the beta subunit of the HLA class II complex, presenting peptides on the surface of antigen presenting cells [12]. In Japan, the HLA gene DRB1*0405 allele was associated with duodenal ulcer [13]. The DRB1*04051 has been shown to be associated with gastric adenocarcinoma independent of $H$. pylori infection [14], and the DRB $1 * 1501$ was negatively related to gastric ulcer, duodenal ulcer and $H$. pylori-associated gastritis when compared to non-infected healthy individuals [13]. The DRB1*1601 allele was found to be associated with increased risk of the diffuse type of stomach cancer in a Swedish population, especially in $H$. pylori negative individuals [15].

The aim of this study was to explore whether there are any associations between the occurrence of IL-1B-31T/C, IL1RN VNTR alleles, IFNGR1-56C/T, HLA DRB1 alleles, together with blood group and life style factors on the one hand, and the occurrence of $H$. pylori infection, peptic ulcer and the grade of inflammation, atrophy and intestinal metaplasia (IM) of the gastric mucosa, on the other hand, in a prospective population based cohort in Sweden.

\section{Methods}

\section{Study population and material}

The study was conducted in accordance with the Helsinki declaration and was approved by the Regional Ethics Committee of Southeast of Sweden. Informed written consent was obtained from all participants. The study population is a cohort of 472 individuals from a larger ( $n=506$ volunteers) population study $[16,17]$. The study includes all individuals that underwent screening with gastroduodenoscopy, biopsy and blood sampling [16] (fasting state), and from whom DNA of sufficient quality for genotyping analysis could be isolated. There were 218 females and 254 males included in the study. Histologic examination of biopsies was performed as previously described [16]. Gastritis was classified according to the Sydney system [16, 18, 19]. The prevalence of chronic gastritis in the corpus was $9.5 \%$ (48.9\% males) and moderate to severe chronic gastritis was observed in $4.0 \%$ of the volunteers (52.6\% males). All ulcers diagnosed at gastroduodenoscopy were biopsied. No malignant ulcers were encountered. According to gastroduodenoscopy and histologic examination of biopsies, $8.7 \%$ of the study population had benign ulcer (58.5\% males) and 3.8\% had ulcer exclusively located in the duodenum (72.2\% males).

Blood samples were stored at $-80{ }^{\circ} \mathrm{C}$ until analysis. $H$. pylori status was classified as positive when at least two of the following occurred: H. pylori identified by light microscopic examination (Giemsa-stained sections), positive result of urease test on fresh biopsy specimen, or elevated level of $H$. pylori IgG antibodies in serum [16], 187 individuals fulfilled the criteria for positive $H$. pylori status (54\% males). Serum pepsinogen I (PGI) and II (PGII) concentrations were analyzed using sandwich enzyme immunoassay (ELISA) as previously described [17]. The reference interval is $2.0-20.0$ for the ratio PGI/PGII and values lower than 3.0 are considered indicative of significant atrophy of the gastric corpus mucosa.

$\mathrm{H}, \mathrm{K}$-ATPase IgG antibodies were analyzed by ELISA as previously described [20] and results are given as relative optical density (OD; upper normal limit 15\%). H. pylori IgG antibodies against surface antigens were analyzed with the same method (upper normal limit of OD 5\% [17]).

\section{Isolation of DNA and whole genome amplification}

DNA was extracted from whole blood at the Department of Forensic Genetics of the Swedish National Board of Forensic Medicine (Linkoping, Sweden), using the M48 BioRobot (Qiagen, Hilden, Germany). In cases from whom no whole blood was available for various reasons, DNA was extracted from plasma or serum using either the QIAamp DNA mini isolation kit (Qiagen, Hilden, Germany) following the blood and body fluid spin protocol, or MagAttract DNA mini M48 kit following the cultured cell protocol. In short, 200 - 400 $\mu \mathrm{L}$ plasma/serum was used and $5 \mu \mathrm{g} \mathrm{dA} / \mathrm{dT}$ DNA carrier probe (GE Healthcare, Uppsala, Sweden) was included in the manual extraction. For automatic extraction using the M48 BioRobot (Qiagen, Hilden, Germany) $400 \mu \mathrm{L}$ plasma/ serum was centrifuged at $3,000 \mathrm{~g}$ for $30 \mathrm{~min}$ at $4{ }^{\circ} \mathrm{C}$, the pellet resuspended in $190 \mu \mathrm{L}$ buffer $\mathrm{G} 2$ and $10 \mu \mathrm{L}$ proteinase $\mathrm{K}$ was added, the samples were incubated at $37^{\circ} \mathrm{C}$ for $0.5-1 \mathrm{~h}$ before extraction and $1 \mu \mathrm{L}$ DNA was used for whole genome amplification according to the GenomiPhi DNA amplification kit (GE Healthcare, Uppsala, Sweden). MDA-DNA concentrations were determined using an ND-1000 spectrophotometer (Nanodrop Technologies, Wilmington, DE, USA). 


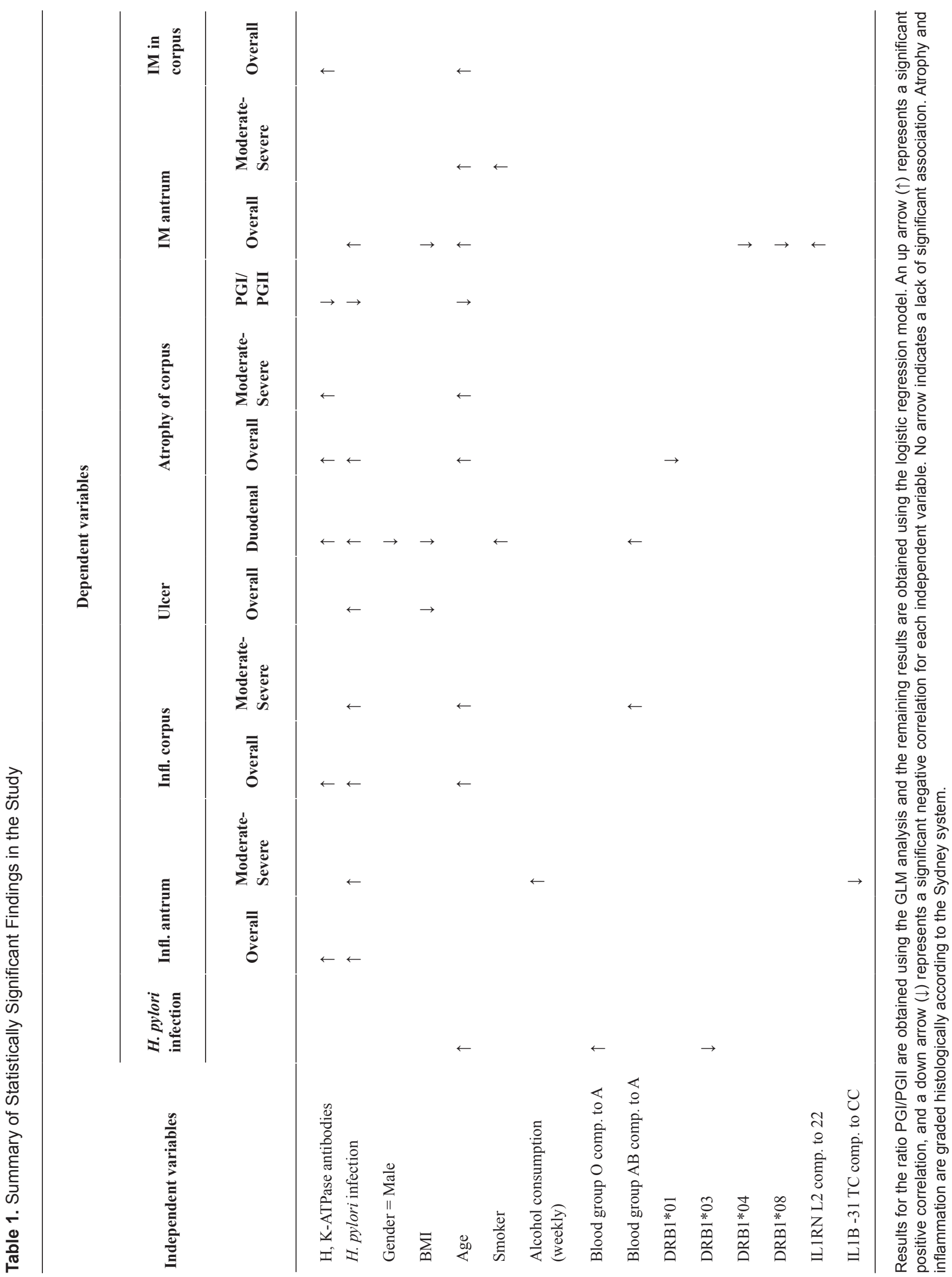




\section{PCR analysis}

The presence of amplified DNA was verified using human $18 \mathrm{~S}$ primers as previously described [21]. Amplification and pyrosequencing analysis of IL1B SNPs rs1143627 (-31C/T), and IFNGR1 SNP rs2234711 (-56T/C), and amplification and gel electrophoresis analysis of IL1RN VNTR in exon 2 were done as previously described [21]. The HLA-DRB1 gene was analyzed at the Department of Forensic Genetics of the Swedish National Board of Forensic Medicine (Linkoping, Sweden), following the recommendation for the HLADR low kit (Olerup, Norway).

\section{Statistical analysis}

The continuous dependent variable PGI/PGII was analyzed using general linear model (GLM) and Minitab (v. 15). All other dependent variables were dichotomous, and were analyzed using forward stepwise (Wald method) binary logistic regression (BLR) and the SPSS statistical analysis program (v. 17). The Hosmer and Lemeshow goodness of fit test was checked at the last step for verification of each analysis. A $\mathrm{P}$-value of $<0.05$ was considered significant.

The independent variables used in the GLM and BLR analyses were: relative OD of $\mathrm{H}, \mathrm{K}$-ATPase antibodies, $H$. pylori infection (this variable was excluded when used as dependent), gender, BMI, age, use of non-steroidal antiinflammatory drugs (NSAID; including low-dose aspirin) on a weekly basis, smoking (yes/no), alcohol consumption (yes/no on a weekly basis [16]), ABO blood group (A, $\mathrm{B}, 0$, and $\mathrm{AB}$ ), Rhesus blood group (+ and -), IL1B genotypes, IFNGR1 genotypes, IL1RN genotypes, and carriers of allele HLA-DRB $1 * 01$, DRB $1 * 03$, DRB $1 * 04$, DRB $1 * 07$, DRB1*08, DRB $1 * 11$, DRB $1 * 13$ and DRB1*15. The chosen HLA-DRB1 alleles were the most frequent (at least 30 alleles in the study counting both homozygote and heterozygote cases (supplementary 1, www.gastrores.org).

\section{Results}

\section{DNA isolation and quality control}

The MDA reaction yielded approximately $750 \mathrm{ng} / \mu \mathrm{L}$ MDADNA in each amplification reaction, and 10 samples were excluded from further analysis due to low quality of DNA, even after repetitive DNA isolation attempts. All included samples (472) generated $18 \mathrm{~S}$ and cytokine PCR products of expected sizes.

\section{Genotype distribution}

The genotype frequency distribution of all analyzed cytokine polymorphisms in this study are presented in supplementary 
Table 3. Result From Binary Logistic Regression Analysis With Chronic Inflammation as Dependent Variable

\begin{tabular}{|c|c|c|c|c|c|c|}
\hline \multirow{2}{*}{$\begin{array}{l}\text { Dependent } \\
\text { variable }\end{array}$} & \multirow{2}{*}{$\begin{array}{l}\text { No. of } \\
\text { positive } \\
\text { cases }\end{array}$} & \multirow{2}{*}{$\begin{array}{l}\text { No. of } \\
\text { included } \\
\text { cases }\end{array}$} & \multirow{2}{*}{$\begin{array}{l}\text { Variables in the } \\
\text { equation }\end{array}$} & \multirow{2}{*}{ P-value ${ }^{b}$} & \multicolumn{2}{|c|}{$95 \%$ CI for OR } \\
\hline & & & & & Lower & Upper \\
\hline \multirow{3}{*}{$\begin{array}{l}\text { Inflammation } \\
\text { overall grade 1-3 } \\
\text { of the corpus }\end{array}$} & \multirow[t]{3}{*}{181} & \multirow[t]{3}{*}{442} & $\mathrm{H}, \mathrm{K}$-ATPase ab & 0.001 & 1.017 & 1.061 \\
\hline & & & H. pylori inf. & 0.000 & 44.090 & 170.14 \\
\hline & & & Age & 0.015 & 1.007 & 1.072 \\
\hline \multirow{6}{*}{$\begin{array}{l}\text { Inflammation } \\
\text { grade } 2-3 \text { of } \\
\text { the corpus }\end{array}$} & \multirow[t]{6}{*}{42} & \multirow[t]{6}{*}{442} & H. pylori inf. & 0.000 & 3.028 & 15.713 \\
\hline & & & Age & 0.007 & 1.013 & 1.088 \\
\hline & & & $\mathrm{ABO}(\mathrm{A})$ & 0.049 & & \\
\hline & & & $\mathrm{ABO}(\mathrm{B})$ & 0.857 & 0.291 & 4.408 \\
\hline & & & $\mathrm{ABO}(\mathrm{O})$ & 0.949 & 0.448 & 2.123 \\
\hline & & & $\mathrm{ABO}(\mathrm{AB})$ & 0.010 & 1.400 & 11.705 \\
\hline \multirow{2}{*}{$\begin{array}{l}\text { Inflammation } \\
\text { overall (grade 1-3) } \\
\text { of the antrum }\end{array}$} & \multirow[t]{2}{*}{181} & \multirow[t]{2}{*}{442} & H, K-ATPase ab & 0.019 & 1.003 & 1.038 \\
\hline & & & H. pylori inf. & 0.000 & 241.34 & 2331.7 \\
\hline \multirow{5}{*}{$\begin{array}{l}\text { Inflammation } \\
\text { grade 2-3 of } \\
\text { the antrum }\end{array}$} & \multirow[t]{5}{*}{114} & \multirow[t]{5}{*}{442} & H. pylori inf. & 0.000 & 55.397 & 509.42 \\
\hline & & & $\begin{array}{l}\text { Alcohol cons. } \\
\text { (weekly) }\end{array}$ & 0.016 & 1.247 & 8.277 \\
\hline & & & IL1B-31 (CC) & 0.026 & & \\
\hline & & & IL1B-31 (TC) & 0.011 & 0.094 & 0.733 \\
\hline & & & IL1B-31 (TT) & 0.140 & 0.169 & 1.285 \\
\hline
\end{tabular}

aHosmer and Lemeshow goodness of fit test was used as indicator of the validity of the equation at the last step of

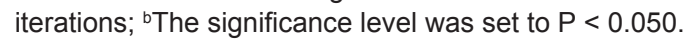

2 (www.gastrores.org). The distribution of IL1B-31 genotype TT/TC/CC was 42.8/42.2/15.0\%. For IFNGR1-56 the distribution of genotype TT/TC/CC was 44.1/42.6/13.3\%. The IL1RN 86bp VNTR genotypes were classified into allele 2 (2 repeats) or $\mathrm{L}$ for three or more repeats [4], and the distribution of genotypes LL/L2/22 was 50.0/39.2/10.8\%. The frequency of HLA-DRB1 allele types is shown in supplementary 1 (www.gastrores.org).

\section{Statistical analysis}

A summary of all analyses in which the regression coefficient was significantly different from zero is shown in Table 1 . The results are grouped according to the dependent variable analyzed; H. pylori status, scores for chronic inflammation of the corpus and antrum mucosa, ulcer overall (duodenal or gastric), duodenal ulcer, any degree of atrophy of the corpus mucosa, moderate to severe atrophy of the corpus mucosa, PGI/PGII as surrogate marker for atrophy of the corpus mucosa, and IM of the corpus and antrum mucosa. The details of each variable analysed are presented below in five parts: H. pylori infection, inflammation, ulcer, atrophy and IM.

Relations between the analyzed polymorphisms and H. pylori status

Results from binary logistic regression analysis of $H$. pylori infection (170 positive cases of 442 examined subjects) are presented in Table 2. H. pylori infection was positively related to age (odds ratio (OR) 95\% CI: $1.027-1.066$ ) and negatively related to presence of the HLA-DRB $1 * 03$ allele (OR 95\% CI: 0.388 - 0.989). There was an overall significant 
Table 4. Result From Binary Logistic Regression for Peptic Ulcer

\begin{tabular}{|c|c|c|c|c|c|c|}
\hline \multirow{2}{*}{$\begin{array}{l}\text { Dependent } \\
\text { variable }\end{array}$} & \multirow{2}{*}{$\begin{array}{l}\text { No. of } \\
\text { positive } \\
\text { cases }\end{array}$} & \multirow{2}{*}{$\begin{array}{l}\text { No. of } \\
\text { included } \\
\text { cases* }\end{array}$} & \multirow{2}{*}{$\begin{array}{l}\text { Variables in the } \\
\text { equation }\end{array}$} & \multirow{2}{*}{$P$-value ${ }^{b}$} & \multicolumn{2}{|c|}{ 95\% CI for OR } \\
\hline & & & & & Lower & Upper \\
\hline \multirow[t]{2}{*}{ Ulcer overall } & 38 & 442 & H. pylori inf. & 0.000 & 4.576 & 28.052 \\
\hline & & & BMI & 0.003 & 0.725 & 0.938 \\
\hline \multirow[t]{9}{*}{ Duodenal ulcer } & 18 & 442 & H, K-ATPase ab & 0.013 & 1.005 & 1.042 \\
\hline & & & H. pylori inf. & 0.005 & 1.678 & 18.377 \\
\hline & & & Gender & 0.031 & 0.077 & 0.885 \\
\hline & & & BMI & 0.012 & 0.663 & 0.950 \\
\hline & & & Smoker & 0.019 & 1.246 & 11.636 \\
\hline & & & $\mathrm{ABO}(\mathrm{A})$ & 0.014 & & \\
\hline & & & $\mathrm{ABO}(\mathrm{B})$ & 0.826 & 0.061 & 9.362 \\
\hline & & & $\mathrm{ABO}(\mathrm{O})$ & 0.416 & 0.477 & 6.017 \\
\hline & & & $\mathrm{ABO}(\mathrm{AB})$ & 0.002 & 2.284 & 46.953 \\
\hline
\end{tabular}

*In some cases data were not available for all variables; a Hosmer and Lemeshow goodness of fit test was used as indicator of the validity of the equation at the last step of iterations; ${ }^{\mathrm{b}}$ The significance level was set to $\mathrm{P}<0.050$.

difference between blood groups $(\mathrm{P}=0.047)$, and in comparisons between pairs of blood groups with $\mathrm{A}$ as reference category, blood group $\mathrm{O}$ showed a higher risk of $H$. pylori infection (OR 95\% CI: 1.121 - 2.677).

Relations between the analyzed polymorphisms and the degree of chronic inflammation of the gastric mucosa

Results from the binary logistic regression analysis of the grade of chronic inflammation in the corpus and antrum mucosa (overall or moderate to severe) are shown in Table 3. Overall inflammation (grade 1-3) in the corpus (181 cases of 442 examined subjects) was associated with elevated levels of H, K-ATPase antibodies (OR 95\% CI: 1.017 - 1.061), H. pylori infection (OR 95\% CI: 44.090 - 170.14), and age (OR 95\% CI: 1.007 - 1.072). When including only individuals with histologically determined moderate to severe (grade 2-3) inflammation of the corpus mucosa (42/442 individuals), there was a positive association with $H$. pylori infection (OR 95\% CI: 3.028 - 15.713), age (OR 95\% CI: 1.013 - 1.088) and a significant difference between $\mathrm{ABO}$ blood groups (P $=0.049)$, where the $\mathrm{AB}$ blood group showed higher risk of moderate to severe inflammation of the corpus mucosa than group A (OR 95\% CI: 1.400 - 11.705).

Overall inflammation (grade 1-3) in the antrum (181/442 subjects) was associated with elevated levels of $\mathrm{H}, \mathrm{K}$-ATPase antibodies (OR 95\% CI: 1.003 - 1.038), and H. pylori infection (OR 95\% CI: 241.34 - 2331.7). Moderate to severe (grade 2-3) inflammation of the antrum (114/442 subjects) was positively related to $H$. pylori infection (OR 95\% CI: 55.397 - 509.42) and alcohol consumption on a weekly basis (OR 95\% CI: 1.247 - 8.277). There was a significant difference between the IL1 $\beta-31$ genotypes $(P=0.026)$ and the TC genotype showed lower risk of moderate to severe inflammation of the antrum than the CC genotype (OR 95\% CI: $0.094-0.733$ ).

Relations between the analyzed polymorphisms and the prevalence of ulcer

Using the binary logistic regression model, peptic ulcer, location disregarded (38/442 subjects), was significantly positively associated with $\mathrm{H}$. pylori infection (OR 95\% CI: 4.576 - 28.052) and with decreasing BMI (OR 95\% CI: 0.725 - 0.938; Table 4). Duodenal ulcer specifically (18/442 subjects) was positively related to the levels of $\mathrm{H}, \mathrm{K}$-ATPase antibodies (OR 95\% CI: $1.004-1.042$ ) and H. pylori infection (OR 95\% CI: 1.678 - 18.377), and more prevalent in women (OR 95\% CI: 0.077 - 0.885), and smokers (OR 95\% CI: 1.246 - 11.636). There was a significant difference between $\mathrm{ABO}$ blood groups $(\mathrm{P}=0.014)$, and group $\mathrm{AB}$ showed higher risk for duodenal ulcer than blood group A (OR 95\% 
Table 5. Result From Binary Logistic Regression Analysis With Atrophy of the Corpus Mucosa as Dependent Variable

\begin{tabular}{|c|c|c|c|c|c|c|}
\hline \multirow{2}{*}{$\begin{array}{l}\text { Dependent } \\
\text { variable }\end{array}$} & \multirow{2}{*}{$\begin{array}{l}\text { No. of } \\
\text { positive } \\
\text { cases }\end{array}$} & \multirow{2}{*}{$\begin{array}{l}\text { No. of } \\
\text { included } \\
\text { cases }\end{array}$} & \multirow{2}{*}{$\begin{array}{l}\text { Variables in the } \\
\text { equation }\end{array}$} & \multirow{2}{*}{ P-value ${ }^{b}$} & \multicolumn{2}{|c|}{ 95\% CI for OR } \\
\hline & & & & & Lower & Upper \\
\hline \multirow{4}{*}{$\begin{array}{l}\text { Atrophy overall } \\
\text { (grade 1-3) of the } \\
\text { corpus }^{\mathrm{c}}\end{array}$} & \multirow[t]{4}{*}{41} & \multirow[t]{4}{*}{442} & H, K-ATPase ab & 0.000 & 1.016 & 1.042 \\
\hline & & & H. pylori inf. & 0.001 & 1.772 & 8.520 \\
\hline & & & Age & 0.004 & 1.018 & 1.101 \\
\hline & & & $\mathrm{DRB} 1 * 01$ & 0.027 & 0.050 & 0.837 \\
\hline \multirow{2}{*}{$\begin{array}{l}\text { Moderate to } \\
\text { severe atrophy of } \\
\text { the corpus }\end{array}$} & \multirow[t]{2}{*}{17} & \multirow[t]{2}{*}{442} & H, K-ATPase ab & 0.001 & 1.010 & 1.038 \\
\hline & & & Age & 0.000 & 1.099 & 1.323 \\
\hline
\end{tabular}

CI: 2.284 - 46.953). There was also a negative relation between BMI (OR 95\% CI: 0.663 - 0.950) and the occurrence of duodenal ulcer.

Relations between the analyzed polymorphisms and the prevalence of atrophy in the corpus mucosa

Results from the binary logistic regression analysis of atrophy of the corpus mucosa (overall or moderate to severe) are shown in Table 5. Results from the statistical analysis using the serum level of the ratio PGI/PGII as surrogate marker for atrophy of the corpus (as determined histomorphologically) are presented in Table 6 . Atrophy of the corpus mucosa (41/442 subjects) was positively related to the levels of H, K-ATPase antibodies (OR 95\% CI: 1.016 - 1.042), $H$. pylori infection (OR 95\% CI: 1.772 - 8.520) and age (OR
95\% CI: $1.018-1.101)$, and negatively related to the presence of HLA-DRB $1 * 01$ (OR 95\% CI: $0.050-0.837$ ). When including only individuals with histologically determined moderate to severe atrophy of the corpus (17/442 subjects), there was a significantly positive association with the $\mathrm{H}, \mathrm{K}$ ATPase antibody levels (OR 95\% CI: 1.010 - 1.038) and age (OR 95\% CI: 1.099 - 1.323).

Using the ratio PGI/PGII as surrogate marker of histologically classified atrophy, GLM analysis revealed a significant negative association between the titer of $\mathrm{H}, \mathrm{K}$-ATPase antibodies (95\% CI: -0.06480 - -0.03024), H. pylori infection (95\% CI: -4.26080 - -2.93031), and age (95\% CI: -0.06470 $-0.00397)$, and the ratio PGI/PGII.

Relations between the analyzed polymorphisms and the presence of IM in the corpus and antrum mucosa

Table 6. Result From GLM Analysis Using the Ratio Pepsinogen I/Pepsinogen II (PGI/PGII) as Surrogate Marker for Atrophy of the Corpus Mucosa

\begin{tabular}{|c|c|c|c|c|c|c|c|}
\hline \multirow{2}{*}{$\begin{array}{l}\text { Dependent } \\
\text { variable }\end{array}$} & \multirow{2}{*}{$\begin{array}{l}\text { Variables in the } \\
\text { equation }\end{array}$} & \multirow{2}{*}{ Coef. } & \multirow{2}{*}{ SE Coef. } & \multirow{2}{*}{$\mathbf{T}$} & \multirow{2}{*}{ P-value ${ }^{a}$} & \multicolumn{2}{|c|}{$95 \%$ CI } \\
\hline & & & & & & Lower & Upper \\
\hline \multirow[t]{3}{*}{ PGI/PGII } & H, K-ATPase ab & -0.047523 & 0.008793 & -5.40 & 0.000 & -0.06480 & -0.03024 \\
\hline & H. pylori inf. & -3.5956 & 0.3385 & -10.62 & 0.000 & -4.26080 & -2.93031 \\
\hline & Age & -0.03434 & 0.01545 & -2.22 & 0.027 & -0.06470 & -0.00397 \\
\hline
\end{tabular}

aThe significance level was set to $\mathrm{P}<0.050$. 
Table 7. Result From Binary Logistic Regression Analysis With Intestinal Metaplasia in the Corpus or Antrum Mucosa as Dependent Variable

\begin{tabular}{|c|c|c|c|c|c|c|}
\hline \multirow{2}{*}{$\begin{array}{l}\text { Dependent } \\
\text { variable }\end{array}$} & \multirow{2}{*}{$\begin{array}{l}\text { No. of } \\
\text { positive } \\
\text { cases }\end{array}$} & \multirow{2}{*}{$\begin{array}{l}\text { No. of } \\
\text { included } \\
\text { cases }\end{array}$} & \multirow{2}{*}{$\begin{array}{l}\text { Variables in the } \\
\text { equation }\end{array}$} & \multirow{2}{*}{ P-value ${ }^{b}$} & \multicolumn{2}{|c|}{$95 \%$ CI for OR } \\
\hline & & & & & Lower & Upper \\
\hline \multirow{2}{*}{$\begin{array}{l}\text { IM in corpus, } \\
\text { grade } 1-3\end{array}$} & \multirow[t]{2}{*}{22} & \multirow[t]{2}{*}{442} & H, K-ATPase ab & 0.001 & 1.018 & 1.042 \\
\hline & & & Age & 0.000 & 1.070 & 1.220 \\
\hline $\begin{array}{l}\text { IM in corpus, } \\
\text { grade } 2-3\end{array}$ & 5 & 442 & $\begin{array}{l}\text { Excluded due to } \\
\text { sign HL test }\end{array}$ & & & \\
\hline \multirow{8}{*}{$\begin{array}{l}\text { IM in antrum, } \\
\text { grade } 1-3\end{array}$} & \multirow[t]{8}{*}{89} & \multirow[t]{8}{*}{442} & H. pylori inf. & 0.000 & 9.675 & 38.480 \\
\hline & & & BMI & 0.001 & 0.758 & 0.927 \\
\hline & & & Age & 0.031 & 1.003 & 1.061 \\
\hline & & & $\mathrm{DRB} 1 * 04$ & 0.011 & 0.234 & 0.831 \\
\hline & & & DRB1*08 & 0.041 & 0.013 & 0.915 \\
\hline & & & IL1RN (22) & 0.013 & & \\
\hline & & & IL1RN (L2) & 0.006 & 1.570 & 15.878 \\
\hline & & & IL1RN (LL) & 0.084 & 0.876 & 8.172 \\
\hline \multirow{2}{*}{$\begin{array}{l}\text { IM in antrum, } \\
\text { grade } 2-3\end{array}$} & \multirow[t]{2}{*}{11} & \multirow[t]{2}{*}{442} & Age & 0.007 & 1.027 & 1.188 \\
\hline & & & Smoking & 0.030 & 1.155 & 17.446 \\
\hline
\end{tabular}

aHosmer and Lemeshow goodness of fit test was used as indicator of the validity of the equation at the last step of

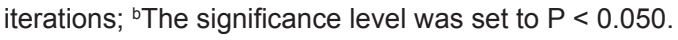

IM in the corpus (22 cases with grade 1-3 out of 442 subjects) was positively associated with the $\mathrm{H}, \mathrm{K}$-ATPase antibody titer (OR 95\% CI: 1.018 - 1.042) and age (OR 95\% CI: $1.070-1.220)$. Only 5 cases of moderate to severe IM in the corpus mucosa were found in this population. The Hosmer and Lemenshow goodness of fit test was significant, indicating a non-valid equation, and the results were excluded from further analysis.

IM in the antrum (89 cases with grade 1-3 out of 442 subjects) was positively associated with $H$. pylori infection (OR 95\% CI: 9.675 - 38.480), and decreasing BMI (OR 95\% CI: 0.758 - 0.927), increasing age (OR 95\% CI: 1.003 $1.061)$, and negatively related to carriage of the HLA DRB1 alleles *04 (OR 95\% CI: 0.234-0.831) and *08 (OR 95\% CI: 0.013 - 0.915) (Table 7). There was an overall significant difference between IL1RN genotypes $(\mathrm{P}=0.013)$, and IL1RN*L2 carriers showed a higher risk of IM in the antrum than genotype *22 carriers (OR 95\% CI: 1.570 - 15.878).

Considering moderate to severe IM in the antrum (grade $2-3 ; 11$ cases), there was a significant relation to increasing age (OR 95\% CI: 1.027 - 1.188) and smoking (OR 95\% CI:
1.155 - 17.446) (Table 7). None of the genotypes was associated with moderate to severe IM.

\section{Discussion}

The aim of this study was to explore possible associations between IL-1B-31T/C, IL1RN VNTR alleles, IFNGR1-56C/T, the HLA DRB1 alleles, blood group and life style factors and $H$. pylori infection, the occurrence of peptic ulcer, grade of gastric mucosal inflammation, atrophy, and IM in a prospective population based cohort in Sweden. The findings are summarized in Table 1. As stated in our first publication concerning this population [17], there was a modest overrepresentation of digestive symptoms among those volunteers that agreed to participate in the screening study compared to an age and sex matched population, which was not being asked to participate in any examinations.

Several human cytokine genes have been thoroughly studied with respect to their influence on the host-microbial interaction of the $H$. pylori colonization, establishment of in- 
fection and the long-term outcome such as duodenal ulcer and the premalignant condition atrophic gastritis. The findings in these studies are not unequivocal and differ in various populations [7]. Two well-studied genes are the IL1 $\beta$ and its receptor antagonist IL1RN. El-Omar et al (2000) [4] showed that mutations in the IL1 $\beta$ gene promoter position -31 (C instead of T) and the short form of the ILIRN VNTR (allele No. 2) were significantly associated with increased risk of developing gastric carcinoma following $H$. pylori infection. In the present study, using logistic regression analysis, no significant association was found between the IL1B-31T/C and $H$. pylori infection, peptic ulcer, gastric atrophy, or IM (Table 1). However, a negative correlation between the $I L 1 B$ 31TC genotype was found for moderate to severe inflammation in the antral mucosa, but not for overall inflammation (grade 1-3 according to the Sydney system) or for any degree of inflammation in the corpus mucosa.

No associations were found between IL1RN VNTR alleles and $H$. pylori infection, any grade of inflammation, ulcer, or atrophy. However, in pairwise comparison between IL1RN genotypes, the *L2 genotype showed a higher risk for IM (grade 1-3) in the antrum (Table 7) than *22. No relation to the IL1RN VNTR alleles was seen when including only cases with moderate to severe IM (11 cases). When searching for papers reporting studies of IL1RN and IM, we found two studies reporting no association between IL1RN*2 genotype and IM [22, 23], and one study reporting an association between IL1RN*2 and IM in an Italian population [24]. However, they do not report any possible association between the IL1RN*L2 genotype and IM, and our findings cannot be verified.

Discussion of the results from each step is presented below in the following order: 1) $\mathrm{H}$. pylori infection; 2) grade of inflammation; 3) ulcer; 4) atrophy of the corpus mucosa; and 5) IM of the corpus and antrum mucosa.

Beside a positive relation to age, we found a higher risk of $H$. pylori infection for the $\mathrm{ABO}$ blood group $\mathrm{O}$ (compared to group A). We also noted a negative relation between the DRB $1 * 03$ allele and $H$. pylori infection. This negative relation was also found by Veneri et al (2005) [25], but their study included only 52 patients with idiopathic thrombocytopenic purpura (of whom 34 had H. pylori infection). Kunstmann et al (2002) [26] found no such relation in a German cohort. The positive association between blood group $\mathrm{O}$ and $H$. pylori infection and gastroduodenal diseases has been described and characterized in other studies [2, 27, 28], but discrepant data regarding this are on record $[29,30]$.

Overall inflammation (grade 1-3) of the corpus mucosa was related to increased titer of $\mathrm{H}, \mathrm{K}$-ATPase antibodies, $H$. pylori infection and increasing age. If only moderate to severe (grade 2-3) inflammation of the corpus was included in the statistical model, no relation to the titer of anti- $\mathrm{H}$, K-ATPase antibodies was found, but there was, however, a higher risk of inflammation of the corpus for blood group $\mathrm{AB}$ than group A. Previously, blood group AB has been found to be negatively associated with $H$. pylori infection [27], a relation that was not observed in this study. To the best of our knowledge, this is the first time a positive relation between moderate to severe inflammation of the corpus mucosa and blood group $\mathrm{AB}$ has been demonstrated.

We found a positive relation between overall inflammation (grade 1-3) in the antrum and $H$. pylori infection and increasing titer of $\mathrm{H}, \mathrm{K}$-ATPase antibodies. However, there was no association between the presence of moderate to severe (grade 2-3) antral inflammation and the titer of anti-H, K-ATPase antibodies. Instead, we noted a relation between weekly alcohol consumption and lower risk of inflammation for the IL1B-31 TC genotype (compared to the CC genotype) (Table 3). To our knowledge, this relation has not been described previously.

For peptic ulcer, location disregarded, a positive relation was found between $H$. pylori infection and low BMI. Regarding individuals with ulcers exclusively located to the duodenum, we found associations to H, K-ATPase antibodies, H. pylori infection, smoking, blood group $\mathrm{AB}$ (compared to group A), female gender and decreasing BMI (Table 1). Sierra et al (2008) [31] also found an association between duodenal ulcer and smoking, but no association between IL1-RN and duodenal ulcer in a Costa Rican dyspeptic population. This is in agreement with our data. The relation to blood group $\mathrm{AB}$ is discordant with the findings of previous investigators who have demonstrated an association between blood group $\mathrm{O}$ and the prevalence of peptic ulcer [32] (reviewed by Anstee and Clarke et al [28, 33]). However, others found no association between $\mathrm{ABO}$ blood groups and ulcer [29].

Regarding atrophy of the corpus mucosa (grade 1-3 according to the Sydney system), a positive relation was found between $\mathrm{H}, \mathrm{K}$-ATPase antibodies, $H$. pylori infection and increasing age, and a negative relation to DRB $1 * 01$ carriage. A negative relation between the DRB $1 * 01$ allele and atrophic gastritis has also been demonstrated by Lahner et al (2010) [34] with an OR of 0.27 (95\% CI 0.08-0.089; P $=0.02$ ). However, we did not find any association between the DRB $1 * 03$ or *04 and atrophic gastritis as found by Lahner et al (2010) [34]. When including only moderate to severe cases of atrophy (grade 2-3) of the corpus mucosa, we found associations to atrophy and $\mathrm{H}, \mathrm{K}$-ATPase antibodies and increasing age. The PGI/PGII ratio is commonly used as a screening marker for AG [35], where a low-value ratio indicates presence of AG. When using the ratio PGI/PGII as surrogate marker for $\mathrm{AG}$ of the corpus, a negative association between $\mathrm{H}, \mathrm{K}$-ATPase antibody titer, $H$. pylori infection, and age and increasing ratio (of PGI/PGII) was noted. This is in accordance with our results for AG overall (grade 1-3 according to the Sydney system), except that no association between PGI/PGII ratio and DRB $1 * 01$ allele carriage emerged.

In this study, IM in the corpus mucosa of grade 1-3 (ac- 
cording to the Sydney system) was found in 22 cases and this was related to increasing titer of $\mathrm{H}, \mathrm{K}$-ATPase antibodies and increasing age (Table 7). Only 5 cases with moderate to severe IM were found in the corpus mucosa of this population. In the statistical analysis, the Hosmer and Lemenshow goodness of fit test was significant, indicating a non-valid equation, and the results were excluded from further analysis.

IM overall (grade 1-3) in the antrum mucosa was found in 89 subjects and was associated with $H$. pylori infection, decreasing BMI, increasing age, the HLA-DRB1 alleles *04 and $* 08$ and the IL1RN *22 (the latter discussed above). IM of moderate to severe grade (2-3) in the antrum mucosa (11 cases) was only associated with increasing age and smoking. The association between IM and increasing age and smoking is well established [36]. The relation of IM in the antrum mucosa and the two HLA-DRB1 alleles *04 and *08 has to our knowledge not been reported before. The findings could not be confirmed for cases with moderate to severe IM in the antrum mucosa (Table 7).

Concerning IFNGR1-56C/T, we found no significant relation to any of the diseases studied here.

In summary, in this prospective Swedish general population based cohort study, we found positive associations between the presence of blood group $\mathrm{O}$ and $H$. pylori infection. We also found a positive association between blood group $\mathrm{AB}$ and moderate to severe inflammation of the corpus mucosa, as well as the occurrence of duodenal ulcer. For the HLA DRB1 alleles, a negative association was found between DRB1*03 and $H$. pylori infection, and for DRB $1 * 04$ and $* 08$ in relation to IM (grade 1-3) of the antrum mucosa. A higher risk of overall IM in the antrum mucosa for heterozygous IL1RN*L2 carriers than *22 carriers, and a lower risk of moderate-severe inflammation of the antrum for IL1 $\beta-31$ TC carriers than CC carriers, were established.

No other significant correlations were identified between the occurrence of the polymorphisms together with life style factors on the one hand, and the occurrence of H. pylori infection, peptic ulcer, and the grade of inflammation, atrophy and IM of the gastric mucosa, on the other hand.

H. pylori infection and age were clearly associated to most of the gastrointestinal diseases studied here. The IL1 RN VNTR and the IL1 $\beta-31$ alleles seem to be associated with IM of the corpus mucosa and the grade of inflammation of the antrum, respectively. However, no unambiguous correlations could be identified between the host polymorphisms and the occurrence of $H$. pylori infection, peptic ulcer, and the grade of inflammation, atrophy and IM of the gastric mucosa.

\section{Acknowledgement}

The authors sincerely thank Erik Mardh for contributing to the analysis of H, K-ATPase antibodies. The study was sup- ported by grants from Research Council in the South-East of Sweden (FORSS and the ALF program).

\section{Conflicts of Interest}

The authors disclose no conflicts.

\section{Author Contributions}

AR has been involved in the acquisition, analysis and interpretation of data, and statistical analysis. FP and SR has participated in the acquisition, analysis and interpretation of data. OE has been involved in the generation and interpretation of statistical analysis data. KB designed the study and participated in the acquisition of data and analysis and interpretation of data. All authors have participated in the drafting of the manuscript and have approved of the final version.

\section{Grant Support}

The study was supported by grants from Research Council in the South-East of Sweden (FORSS and the ALF program).

\section{References}

1. Kandulski A, Selgrad M, Malfertheiner P. Helicobacter pylori infection: a clinical overview. Dig Liver Dis. 2008;40(8):619-626.

2. Wroblewski LE, Peek RM, Jr., Wilson KT. Helicobacter pylori and gastric cancer: factors that modulate disease risk. Clin Microbiol Rev. 2010;23(4):713-739.

3. Yeomans ND. The ulcer sleuths: The search for the cause of peptic ulcers. J Gastroenterol Hepatol. 2011;26(Suppl 1):35-41.

4. El-Omar EM, Carrington M, Chow WH, McColl KE, Bream JH, Young HA, Herrera J, et al. Interleukin-1 polymorphisms associated with increased risk of gastric cancer. Nature. 2000;404(6776):398-402.

5. Furuta T, El-Omar EM, Xiao F, Shirai N, Takashima M, Sugimura H. Interleukin 1beta polymorphisms increase risk of hypochlorhydria and atrophic gastritis and reduce risk of duodenal ulcer recurrence in Japan. Gastroenterology. 2002;123(1):92-105.

6. Garcia-Gonzalez MA, Savelkoul PH, Benito R, Santolaria S, Crusius JB, Pena AS, Lanas A. No allelic variant associations of the IL-1 and TNF gene polymorphisms in the susceptibility to duodenal ulcer disease. Int J Immunogenet. 2005;32(5):299-306.

7. Persson C, Canedo P, Machado JC, El-Omar EM, For- 
man D. Polymorphisms in inflammatory response genes and their association with gastric cancer: A HuGE systematic review and meta-analyses. Am J Epidemiol. 2011;173(3):259-270.

8. Camargo MC, Mera R, Correa P, Peek RM, Jr., Fontham ET, Goodman KJ, Piazuelo MB, et al. Interleukin-1beta and interleukin-1 receptor antagonist gene polymorphisms and gastric cancer: a meta-analysis. Cancer Epidemiol Biomarkers Prev. 2006;15(9):1674-1687.

9. Thye T, Burchard GD, Nilius M, Muller-Myhsok B, Horstmann RD. Genomewide linkage analysis identifies polymorphism in the human interferon-gamma receptor affecting Helicobacter pylori infection. Am J Hum Genet. 2003;72(2):448-453.

10. Cooke GS, Campbell SJ, Sillah J, Gustafson P, Bah B, Sirugo G, Bennett $S$, et al. Polymorphism within the interferon-gamma/receptor complex is associated with pulmonary tuberculosis. Am J Respir Crit Care Med. 2006;174(3):339-343.

11. Zhou J, Chen DQ, Poon VK, Zeng Y, Ng F, Lu L, Huang $\mathrm{JD}$, et al. A regulatory polymorphism in interferon-gamma receptor 1 promoter is associated with the susceptibility to chronic hepatitis B virus infection. Immunogenetics. 2009;61(6):423-430.

12. Turner D. The human leucocyte antigen (HLA) system. Vox Sang. 2004;87 (Supp11):87-90.

13. Yoshitake S, Okada M, Kimura A, Sasazuki T. Contribution of major histocompatibility complex genes to susceptibility and resistance in Helicobacter pylori related diseases. Eur J Gastroenterol Hepatol. 1999;11(8):875880 .

14. Ohtani M, Azuma T, Yamazaki S, Yamakawa A, Ito Y, Muramatsu A, Dojo M, et al. Association of the HLADRB1 gene locus with gastric adenocarcinoma in Japan. Dig Liver Dis. 2003;35(7):468-472.

15. Magnusson PKE, Enroth H, Eriksson I, Held M, Nyren $\mathrm{O}$, Engstrand L, Hansson LE, et al. Gastric cancer and human leukocyte antigen: distinct DQ and DR alleles are associated with development of gastric cancer and infection by Helicobacter pylori. Cancer Res. 2001;61(6):2684-2689.

16. Borch K, Jonsson KA, Petersson F, Redeen S, Mardh S, Franzen LE. Prevalence of gastroduodenitis and Helicobacter pylori infection in a general population sample: relations to symptomatology and life-style. Dig Dis Sci. 2000;45(7):1322-1329.

17. Redeen S, Petersson F, Kechagias S, Mardh E, Borch K. Natural history of chronic gastritis in a population-based cohort. Scand J Gastroenterol. 2010;45(5):540-549.

18. Price AB. The Sydney System: histological division. J Gastroenterol Hepatol. 1991;6(3):209-222.

19. Dixon MF, Genta RM, Yardley JH, Correa P. Classification and grading of gastritis. The updated Sydney System. International Workshop on the Histopathol- ogy of Gastritis, Houston 1994. Am J Surg Pathol. 1996;20(10):1161-1181.

20. Ma JY, Borch K, Sjostrand SE, Janzon L, Mardh S. Positive correlation between $\mathrm{H}, \mathrm{K}$-adenosine triphosphatase autoantibodies and Helicobacter pylori antibodies in patients with pernicious anemia. Scand J Gastroenterol. 1994;29(11):961-965.

21. Ryberg A, Borch K, Sun YQ, Monstein HJ. Concurrent genotyping of Helicobacter pylori virulence genes and human cytokine SNP sites using whole genome amplified DNA derived from minute amounts of gastric biopsy specimen DNA. BMC Microbiol. 2008;8:175.

22. Kupcinskas L, Wex T, Kupcinskas J, Leja M, Ivanauskas A, Jonaitis LV, Janciauskas D, et al. Interleukin-1B and interleukin-1 receptor antagonist gene polymorphisms are not associated with premalignant gastric conditions: a combined haplotype analysis. Eur J Gastroenterol Hepatol. 2010;22(10):1189-1195.

23. Murphy G, Thornton J, McManus R, Swan N, Ryan B, Hughes DJ, O'Morain CA, et al. Association of gastric disease with polymorphisms in the inflammatory-related genes IL-1B, IL-1RN, IL-10, TNF and TLR4. Eur J Gastroenterol Hepatol. 2009;21(6):630-635.

24. Zambon CF, Basso D, Navaglia F, Germano G, Gallo N, Milazzo M, Greco E, et al. Helicobacter pylori virulence genes and host IL-1RN and IL-1beta genes interplay in favouring the development of peptic ulcer and intestinal metaplasia. Cytokine. 2002;18(5):242-251.

25. Veneri D, De Matteis G, Solero P, Federici F, Zanuso C, Guizzardi E, Arena S, et al. Analysis of B- and T-cell clonality and HLA class II alleles in patients with idiopathic thrombocytopenic purpura: correlation with Helicobacter pylori infection and response to eradication treatment. Platelets. 2005;16(5):307-311.

26. Kunstmann E, Hardt C, Treitz H, Suerbaum S, Faller G, Peitz U, Schmiegel W, et al. In the European population HLA-class II genes are not associated with Helicobacter pylori infection. Eur J Gastroenterol Hepatol. 2002;14(1):49-53.

27. Kanbay M, Gur G, Arslan H, Yilmaz U, Boyacioglu $\mathrm{S}$. The relationship of $\mathrm{ABO}$ blood group, age, gender, smoking, and Helicobacter pylori infection. Dig Dis Sci. 2005;50(7):1214-1217.

28. Anstee DJ. The relationship between blood groups and disease. Blood. 2010;115(23):4635-4643.

29. Keller R, Dinkel KC, Christl SU, Fischbach W. Interrelation between $\mathrm{ABH}$ blood group 0, Lewis(B) blood group antigen, Helicobacter pylori infection, and occurrence of peptic ulcer. Z Gastroenterol. 2002;40(5):273276.

30. Robertson MS, Cade JF, Savoia HF, Clancy RL. Helicobacter pylori infection in the Australian community: current prevalence and lack of association with $\mathrm{ABO}$ blood groups. Intern Med J. 2003;33(4):163-167. 
31. Sierra R, Une C, Ramirez V, Alpizar-Alpizar W, Gonzalez MI, Ramirez JA, De Mascarel A, et al. Relation of atrophic gastritis with Helicobacter pylori-CagA(+) and interleukin-1 gene polymorphisms. World J Gastroenterol. 2008;14(42):6481-6487.

32. Suadicani P, Hein HO, Gyntelberg F. Genetic and lifestyle determinants of peptic ulcer. A study of 3387 men aged 54 to 74 years: The Copenhagen Male Study. Scand J Gastroenterol. 1999;34(1):12-17.

33. Clarke CA, Edwards JW, Haddock DR, Howel-Evans AW, McConnell RB, Sheppard PM. ABO blood groups and secretor character in duodenal ulcer; population and sibship studies. Br Med J. 1956;2(4995):725-731.

34. Lahner E, Spoletini M, Buzzetti R, Corleto VD, Vannella L, Petrone A, Annibale B. HLA-DRB $1 * 03$ and DRB $1 * 04$ are associated with atrophic gastritis in an Italian population. Dig Liver Dis. 2010;42(12):854-859.

35. Mardh E, Mardh S, Mardh B, Borch K. Diagnosis of gastritis by means of a combination of serological analyses. Clin Chim Acta. 2002;320(1-2):17-27.

36. Zullo A, Hassan C, Romiti A, Giusto M, Guerriero C, Lorenzetti R, Campo SM, et al. Follow-up of intestinal metaplasia in the stomach: When, how and why. World J Gastrointest Oncol. 2012;4(3):30-36. 